\title{
Afghanistan, the Amu Darya Basin and Regional Treaties
}

\author{
Ikramuddin KAMIL | ORCID: 0000-0002-1436-1152 \\ Doctoral Candidate, Faculty of Legal Studies, South Asian University, New \\ Delhi, India \\ Ikramuddin129@gmail.com
}

\begin{abstract}
The Amu Darya Basin is included in various bilateral and regional treaties negotiated between Afghanistan and Russia/the former UssR, and among the Central Asian Republics. The former are boundary treaties, and do not cover the use of the Amu Darya. The latter are, inter alia, water-sharing agreements that govern the use of water. This article examines the current legal regime governing the Amu Darya. It addresses one specific question: What are the legal implications for Afghanistan of its exclusion from the regional legal framework governing the apportionment and utilization of the Amu Darya? The article argues that sustainable water resource management is dependent on the participation of all riparian states in the management of a shared watercourse and without Afghanistan's inclusion in the regional water agreements or organizations governing the Amu Darya, no Central Asian regional water agreement or organization is complete. The article makes two further arguments. First, the equitable and reasonable utilization principle gives all riparian states the right to an equitable share in shared watercourses, therefore the downstream Central Asian Republics cannot prevent upstream Afghanistan from developing its freshwater resources. Second, even though Afghanistan is not a party to the agreements governing the use of the Amu Darya waters, the country can still be affected or harmed by downstream uses of these waters, as Afghanistan's future use of the Amu Darya can be foreclosed or limited.
\end{abstract}

\section{Keywords}

Afghanistan - Central Asia - treaty law - Amu Darya - transboundary watercourse international water law - equitable and reasonable utilization - no harm rule foreclosure of future use 
Afghanistan has a significant amount of fresh water, sourced from precipitation in the high mountains of Hindu Kush. ${ }^{1}$ It is estimated that Afghanistan has 75 billion cubic meters of potential water resources, 57 billion cubic meters of surface water, and 18 billion cubic meters is groundwater. ${ }^{2}$ Afghanistan uses 35 percent of the total surface water, which comes from five main river basins: ${ }^{3}$ the Amu Darya Basin ('darya' is the Persian word for river), the Kabul River Basin or Indus River Basin, the Helmand River Basin, the Harirud-Marghab River Basin, and the Northern River Basin. ${ }^{4}$ Except for the Northern River, the rivers are transboundary and flow outwards from Afghanistan into neighbouring countries.

The water of the Amu Darya is mostly used for agriculture, and its allocation is a legacy of the policies of the former Union of Soviet Socialist Republics (USSR) or Soviet Union. The water of the Amu Darya was allocated among the four Central Asian Republics (CARs) namely, Tajikistan, Uzbekistan, Turkmenistan, and the Kyrgyz Republic through Protocol 566 adopted by the former UssR. ${ }^{5}$ Immediately after the independence of the CARs in 1991, they concluded a new agreement commonly known as Almaty Agreement, that retained the Protocol 566 allocation quotas. Tajikistan, Uzbekistan, Turkmenistan, Kyrgyz Republic, and Kazakhstan ${ }^{6}$ (collectively called CARs) have also established multiple organizations and institutions for the management of the Amu Darya and the Syr Darya. Afghanistan was not included in these regional agreements. ${ }^{7}$

1 Masood AHMAD and Mahwash WASIQ, Water Resources Development in Northern Afghanistan and its Implications for Amu Darya Basin (No. 36, World Bank Publications 2004) 9 <http://documents.worldbank.org/curated/en/434761468767735o8o/Water-resourc e-development-in-Northern-Afghanistan-and-its-implications-for-Amu-Darya-basin>.

2 ibid. Afghanistan National Water Affairs Regulation Authority (NWARA) in a comment on early drafts of this article mentioned that the total water available in Afghanistan has dropped sharply from 75 billion cubic meters to 67 billion cubic meters in the past two decades. However, since the author was not given authentic data, it had to rely on a 2004 World Bank study.

3 Government of the Islamic Republic of Afghanistan, 'Afghanistan National Development Strategy 2008-2013' (2008) 8 <https://www.wto.org/english/thewto_e/acc_e/afg_e/wtac cafg18_cd_1.pdf>.

4 ibid.

5 Protocol 566: Improvement of the Scheme on Complex Use and Protection of Amu-Darya Water Resources by Scientific \& Technical Council, Ministry of Land Reclamation and Water Management of the USSR (1987) (hereinafter Protocol 566).

6 Kazakhstan is a riparian to Syr Darya, which originates in the Kyrgyz Republic and flows through Tajikistan, Uzbekistan, and Kazakhstan before terminating in the Aral Sea.

7 The binding and non-binding instruments of the CARs that deal with water management of the Amu Darya include: Agreement between the Republic of Kazakhstan, the Republic 
On the other hand, Afghanistan and Great Britain have concluded number of agreements with Russia and later USSR on the demarcation of the boundary between Afghanistan and former ussR/Russia. The Amu Darya was recognized under these agreements as a boundary between Afghanistan and USSR/ Russia. ${ }^{8}$ However, these agreements do not address the issue of allocation of Amu Darya between Afghanistan and CARs. The questions arising from this arrangement are as follows: What could be the possible legal implications under international law when an upper riparian state is excluded from a

of Kyrgyzstan, the Republic of Uzbekistan, the Republic of Tajikistan and Turkmenistan on Cooperation in the Field of Joint Water Resources Management and Conservation of Interstate Sources (1992) (hereinafter Almaty Agreement); the Statute of the Interstate Commission for Water Coordination in Central Asia (ICWC) (1992) (hereinafter ICWC Statute 1992); the Agreement about the Status of IFAS and Its Organizations (1999) (hereinafter IfAS Agreement); the Statute of the Basin Water Association 'Amudarya' (1992); the Nukus Declaration of the Central Asian States and International Organizations on the Problems of Sustainable Development in the Aral Sea Basin, Nukus (1995) (hereinafter Nakus Declaration); the Almaty Declaration of the Heads of States of the Republic of Kazakhstan, the Kyrgyz Republic, the Republic of Tajikistan, Turkmenistan and the Republic of Uzbekistan, Almaty (1997) (hereinafter Almaty Declaration); the Joint Statement Made by the Heads of States of the Republic of Kazakhstan, the Kyrgyz Republic, the Republic of Tajikistan, Turkmenistan and the Republic of Uzbekistan (1999); the Dushanbe Declaration of the Heads of States of the Republic of Kazakhstan, the Kyrgyz Republic, the Republic of Tajikistan, Turkmenistan and the Republic of Uzbekistan, Dushanbe (2002) (hereinafter Dushanbe Declaration); the Joint Statement Made by the Heads of States - Founders of the International Fund for Saving the Aral Sea, Almaty (2009), and the Framework Convention on Environmental Protection for Sustainable Development in Central Asia (2006 not in force); Draft Statute of the ICWC (2008) (hereinafter ICWC Statute 2006).

8 The first agreement related to Amu Darya was the Treaty of Commerce and Navigation between Great Britain and Russia (1843) which was later followed by Protocol on Delimitation (1885); Treaty of Friendship between Afghanistan and the Soviet Union (1921); Treaty between the Union of Soviet Socialist Republics and Afghanistan of neutrality and non-aggression 157 UNTS 371 (1931); Frontier Agreement between Afghanistan and the Union of Soviet Socialist Republic (including Exchange of Notes) 31 UNTS 158 (1946) (hereinafter 1946 Agreement); Treaty between the Government of the USSR and the Royal Government of Afghanistan Concerning the Regime of the Soviet-Afghanistan State Frontier (with annexes and Protocols) 321 UNTS 166 (hereinafter 1958 Agreement); Protocol between the USSR and Afghanistan on the Joint Execution of Works for the Integrated Utilization of the Water Resources in the Frontier Section of the Amu Darya (1958); Agreement on Economic and Technical Cooperation during the Period 1967-1972 (with annexes) 31 UNTS 124 (1968); Treaty of Friendship, Good-neighbourliness and Cooperation 1145 UNTS 133 (1978); The Joint Meeting Protocol Delegation of Ministry of Energy \& Water, Islamic Republic of Afghanistan and Ministry of Melioration \& Water Resources and Ministry of Agriculture and Environment, Republic of Tajikistan (2007) (hereinafter Afghanistan-Tajikistan $2007 \mathrm{MoU}$ ) and Memorandum of Understanding on Exchange of Hydrological Data and Information relating to the Panj-Amu Darya River Basin between the State Authorities of the Islamic Republic of Afghanistan and the Republic of Tajikistan for the Period of 2015-2017 and Prospectively until 2020 (2014) (hereinafter Afghanistan-Tajikistan $2014 \mathrm{MoU}$ ). 
regional water treaty? Have the Amu Darya regional agreements created any rights for or imposed any obligations on Afghanistan, which is not a party to any of these agreements? If the answer to this question is in the affirmative, then what are the legal implications of a third-party creating rights and obligations under international law?

This article argues that the CARs, through regional agreements, cannot create rights and obligations for Afghanistan. However, customary international law principles to which Afghanistan is not a persistent objector and that the CARs have incorporated into regional agreements will apply to Afghanistan as a rule of customary international law. In addition, the general principle of equitable and reasonable utilization as codified by the UN Convention on the Law of Non-Navigational Uses of International Watercourses (1997 UN Convention $)^{9}$ favours early developers. However, it also recognizes that late developers have the right to develop water resources despite the harm caused to early developers. Moreover, Afghanistan could be harmed by downstream state(s)' (in this case, the CARs') expansion of water utilization, as this would forestall potential and future uses by Afghanistan. Hence, both sides (upstream and downstream users) have an obligation to each other, and they must consider each other's current and future uses in developing plans and projects on the shared river.

This article first describes the Amu Darya Basin, the Soviet legacy of water management in the Aral Sea Basin and the political reasons for Afghanistan's exclusion from the regional water management agreements. It then presents an overview and analysis of the legal regime governing the Amu Darya. Finally, it focuses on the legal implications for Afghanistan of its exclusion from regional water-sharing agreements.

The Amu Darya (also called the Oxus) is the longest river in Central Asia, originating from the Hindu Kush and Wakhan in the Pamir Highlands in Afghanistan, and flows 2,540 kilometres to the Aral Sea in Central Asia. ${ }^{10}$ The upper part of the Amu Darya Basin after the confluence of headwaters (the Wakhan River) with the Pamir River, is called Panj. After the Panj River joins

9 Convention on the Law of the Non-Navigational Uses of International Watercourses, in Annex of UN General Assembly resolution 51/229 (1997) (hereinafter UN Convention 1997).

10 Masood AHMAD and Mahwash WASIQ (n 1 ) 10. The Amu Darya forms a border between Afghanistan and Tajikistan and then Uzbekistan, crosses the territory of Turkmenistan and returns to Uzbekistan, where it is discharged into the Aral Sea. 
the Vakhsh River, which flows from the Alai in Kyrgyzstan, it is called the Amu Darya. ${ }^{11}$ The Amu Darya forms a frontier of 1800 kilometres between Afghanistan and its northern neighbours, beginning from Zor-Kul and ending at Khamaab. The main tributaries of the Amu Darya are the Pamir, Wakhan, Shiwa, Kokacha, Kunduz, Vakhsh, Kafiernigann, Surkhandarya, and Sherabaddarya Rivers. The Payandzh and Wakhsh are the largest tributaries of the Amu Darya. ${ }^{12}$ These rivers are mountain tributaries, and the Amu Darya has no significant tributaries along its 1,200 kilometres through the plain. ${ }^{13}$ The annual average flow of the Amu Darya is $75 \mathrm{bcm}$ ('bcm' means 'basin characterisation model'; it refers to a calculation of annual precipitation, including snowfall). The flow reaches $108 \mathrm{bcm}$ in high-water years and $47 \mathrm{bcm}$ in dry or low-water years. ${ }^{14}$ The catchment area of the Amu Darya is 309,000 square kilometres. ${ }^{15}$

The Amu Darya is the most productive water source for Afghanistan and the region. ${ }^{16}$ The total irrigated area of the Amu Darya is estimated at 6 million hectares. In upstream Afghanistan, it irrigates 1.15 million hectares of land. ${ }^{17}$ Downstream, Uzbekistan has the largest irrigated area (2.3 million hectares), followed by Turkmenistan, where the Amu Darya is utilized to irrigate 1.7 million hectares of land. In upstream Tajikistan, the Amu Darya is used for 0.5 million hectares of land, and in the Kyrgyz Republic, it is used for only about 0.1 million hectares of land. ${ }^{18}$

Since the Amu Darya is the one of the most significant and productive water sources for Afghanistan in the region, this article argues that it is essential for all relevant stakeholders to pursue a cooperative strategy rather than a unilateral strategy of capturing resources, to shift attitudes towards cooperation and to engage in meaningful dialogue.

\footnotetext{
11 ibid 10.

12 Najib A FAHIM, Legal System Governing Amu Darya Basin, (Centre for Strategic Studies 2017) 13 .

13 Masood AHMAD and Mahwash WASIQ (n 1$) 12$.

14 ibid.

15 Kai WEGEROCH, 'Hydro-hegemony in the Amu Darya Basin' (2008) 10(2) Water Policy 73

16 Maps of the Amu Darya Basin can be found at CAWATERinfo http://www.cawater-info .net/map_e.htm. and at Afghanistan Waters Portal https://afghanwaters.net/en/map -amu-river-basin/.

17 Masood AHMAD and Mahwash WASIQ (n 1) 25; Stuart HORSMAN, 'Afghanistan and Transboundary Water Management on the Amu Darya: A Political History' in M.M. RAHAMAN and O. VARIS (eds), Central Asian Waters: Social, Economic, Environmental and Governance Puzzle (Helsinki University of Technology 2008) 65 .

Masood AHMAD and Mahwash WASIQ (n 1$) 25$.
} 
The Aral Sea was the fourth-largest inland body of water on the planet in the 1950s, containing 109 o cubic kilometres of water and covering 66,ooo square kilometres of surface area. ${ }^{19}$ Almost half of the water from the Amu Darya and Syr Darya reached the Aral Sea, and these rivers sustained the sea's stability. ${ }^{20}$ However, in the span of just four decades, the Aral Sea basin was transformed into a major ecological and socioeconomic disaster. ${ }^{21}$ This was because of the policies of the former UssR, which diverted the water of the Amu Darya and the Syr Darya for the expansion of cotton production in the arid region.

The water of the Amu Darya and Syr Darya is mostly used for agriculture. In the 1970s, the USSR expanded the irrigated area by $15^{\circ}$ percent in the Amu Darya Basin only. ${ }^{22}$ These irrigated areas have also expanded in recent decades. ${ }^{23}$ The UssR perceived that the value of agriculture and animal husbandry output in the Aral Sea Basin outweighed the effects of environmental damage to the area. ${ }^{24}$ Therefore, the USSR authorities implemented agricultural policies that encouraged cotton production. ${ }^{25}$ Their continuing demand was to increase the production of cotton, or 'white gold', at any cost. ${ }^{26}$ They expanded the irrigated area to 7.2 million hectares in 1975 and to 9.4 million hectares by $1989 .{ }^{27}$ The CAR s, especially Uzbekistan, become the largest cotton producers; however, they processed very little cotton, and most of the harvest was transported to the central and western parts of the USSR, where it was used as an input for textile industries. ${ }^{28}$

It was agreed that Turkmenistan and Uzbekistan, which are downstream riparian state(s), would produce cotton, while upstream Tajikistan would use

19 Michael H GLANTZ, 'Sustainable Development and Creeping Environmental Problems in the Aral Sea region' in Michael H GLANTZ (ed), Creeping Environmental Problems and Sustainable Development in the Aral Sea Basin (CUP 1999) 8.

20 ibid.

21 ibid.

22 Julia BUCKMALL et al, Irrigation in Central Asia - Social, Economic and Environmental Considerations (The World Bank 2003) 3.

23 Behzod GAYBULLAEV, Su C CHEN and Dilmurod GAYBULLAEV, 'Changing in Water of the Aral Sea After 196o' (2012) 2 Applied Water Science 285-286.

24 Kai WEGERICH, 'The New Great Game: Water allocation in Post-Soviet Central Asia' (2009) 10 Georgetown Journal of International Affairs 118.

25 ibid.

26 Sarah L O'HARA ‘Central Asia's Water Resources: Contemporary and Future Management Issues' (2000) 16(3) International Journal of Water Resources Development 423.

27 WEGERICH, 'The New Great Game' (n 24) 118.

28 Max SPOOR and Anatoly KRUTOV, 'The Power of Water in a Divided Central Asia', (2003) 10(3-4) Perspectives on Global Development and Technology 596. 
the water for energy production. ${ }^{29}$ However, Afghanistan and Kyrgyzstan were considered providers of water only, without real water rights. ${ }^{30}$ The reservoirs that were constructed in Kyrgyzstan were to provide downstream Uzbekistan and Kazakhstan with water so that they could expand their agriculture. In exchange for natural gas, coal, and oil, Kazakhstan would receive water from downstream state(s). ${ }^{31}$ The USSR maintained its hydro-hegemony against Afghanistan, a weaker neighbour, and had not included the country in the 1987 meetings that determined the allocations of the four Soviet Republics in the basin. ${ }^{32}$ These meetings ended with the adoption of Protocol 566 by the Scientific and Technical Council of the UssR's Ministry of Water Resources. The protocol determined water allocation quotas for the four Soviet republics and created the River Basin Organizations (Basseynoe Vodnoe Ob'edinenie, or 'BVO') for the management and enforcement of these quotas. With the dissolution of the USSR in 1991, in 1992, the five CARs (Kazakhstan, Kyrgyz Republic, Tajikistan, Turkmenistan, and Uzbekistan) entered into a new agreement, where they maintained the quotas set by Protocol 566 and created the Interstate Commission for Water Coordination of Central Asia (ICWC) for the management of water allocation. Afghanistan, an upper riparian state, is not a party to the Almaty Agreement or the ICWC. The subsequent section analyses the reasons of Afghanistan's non-inclusion in the regional treaty arrangements that govern the allocation of Amu Darya resources.

There are multiple reasons for Afghanistan's exclusion from these regional water-sharing agreements and organizations. Horsman highlights these reasons which include practicalities, regional relations, regional attitudes toward cooperation, institutional inertia and self-interest, and upstream and downstream differences. ${ }^{33}$ This section analyses these political reasons for Afghanistan's exclusion from regional water management.

The first is the practical situation of Afghanistan. Afghanistan can increase the land under irrigation from the Amu Darya by only 20 percent, which would

\footnotetext{
29 WEGERICH, 'Hydro-hegemony in the Amu Darya Basin' (n 15) 77.

$30 \quad$ ibid 71.

31 Dinara KEMELOVA and Gennady ZHALKUBAEV, 'Water, Conflict, and Regional Security in Central Asia Revisited' (2003) 11 New York University Environmental Law Journal 480.

32 WEGERICH, 'Hydro-hegemony in the Amu Darya Basin' (n 15) 76.

33 HORSMAN (n 17) 67-70.
} 
raise Afghanistan's diversion from the river to $5^{-6}$ cubic kilometres, that is still less than 2 percent of the total river supply; achieving this increase would take two decades. ${ }^{34}$ As a result, Afghanistan's neighbours do not feel a sense of competition to incentivize the reaching of a water-sharing agreement with Afghanistan. The need for Afghanistan to be a party to the existing agreements and organizations managing the Amu Darya is not a priority for them. The second reason is Afghanistan's domestic situation, which has profound implications for its neighbours' relations. Afghanistan has been facing a war for the last 40 years; its governments have been unstable and weak and either unable or uninterested in cooperating with the country's neighbours. ${ }^{35}$ GLEICK points out that the political context is vital for trans-state management. ${ }^{36}$ The third reason is that not all Amu Darya basin's stakeholders in Central Asia share the same values and interests in promoting regional cooperation. They take unilateral actions to manage water resources. Their laws define water as national wealth rather than a public or common good. Hence, Afghanistan's exclusion suggests a lack of commitment to the goals of the Almaty Agreement and other agreements governing the Amu Darya, which emphasize equitable utilization and the concept of equal rights and responsibilities. ${ }^{37}$ The fourth reason for Afghanistan's exclusion is that the parties to the CAR s' regional and sub-regional organizations, out of self-interest, do not want to change their existing institutional framework. Afghanistan may pose challenges to existing members' interests, which are favoured under the current institutional mechanisms. The membership of Afghanistan could challenge the status quo and the interests of the downstream states in particular. ${ }^{38}$ The fifth reason concerns upstream and downstream differences. There are two different competing interests related to Amu Darya utilization. Afghanistan and Tajikistan (upstream states) see the Amu Darya as a source of hydro-electric power (HEP) and irrigation. However, downstream Turkmenistan and Uzbekistan see the river mainly as a source of irrigation for cotton and rice production. Upstream Afghanistan and Tajikistan are planning to expand HEP production, and therefore, their plans may lead to disputes with downstream Turkmenistan and Uzbekistan. ${ }^{39}$

\footnotetext{
34 ibid 67-68; see Masood AHMAD and Mahwash WASIQ (n 1) 3-41.

35 HORSMAN (n 17) 69.

36 Pater H GLEICK, 'Water and Conflict: Fresh Water Resources and International Security' (1993) 18(1) International Security 85.

37 HORSMAN (n 17) 69 .

38 ibid.

39 ibid 70.
} 
Afghanistan's exclusion from regional water-sharing and management treaties and organizations makes it quite challenging for CARs to achieve sustainable management of transboundary water resources in the region, as effective transboundary management is dependent on the participation of all riparian states in the management of a basin. Therefore, it can be concluded that the entire regional water management regime in Central Asia is incomplete without Afghanistan's inclusion.

\section{5 Current Legal Regime Managing the Amu Darya}

This section briefly examines the legal regime that governs the Amu Darya. Two kinds of agreements regulating the Amu Darya are still in force. The first are agreements between Afghanistan and the former UssR/Russia, while the second are agreements between the CARs. The former are boundary agreements and do not cover the issue of water sharing. The latter agreements are water sharing and water management agreements and provide an institutional framework. Afghanistan is not a party to any agreements that govern the water allocation of the Amu Darya.

\subsection{Agreements between Afghanistan and Russia or the Former UssR}

The first treaty over the Amu Darya was the Treaty of Commerce and Navigation between Great Britain and Russia of 1843, which stipulated rules of navigation and commerce on the Amu Darya. The 1872 and 1873 agreements between Great Britain and Russia and the 1946 and 1958 agreements between Afghanistan and Russia primarily focused on the Amu Darya as an international boundary. Furthermore, the 1921 Treaty of Friendship between Afghanistan and Russia provided that Russia had to give back all territories in the frontier zone, which had been Afghanistan's property in the past century. The most relevant treaties for this discussion are the 1946 and 1958 treaties.

The 1946 agreement between Afghanistan and Russia assured Afghanistan's navigation rights on the Amu Darya and the navigable part of the Pyandzh (or Panj) River. ${ }^{40}$ The agreement also established a joint commission that was supposed to meet regularly, map the frontier line, determine ownership of islands, and set up boundary posts where it was considered necessary. ${ }^{41}$ Moreover, the note of exchange annexed to the 1946 treaty and an integral part of the treaty provided that Afghanistan would maintain the status quo and not increase the

$40 \quad 1946$ Agreement (n 8) article 1.

41 ibid article 2. 
quantity of water taken from the Kushka River. The note also emphasized that the USSR would not build a dam on the Murghab River or utilize the Afghan bank of the river. However, this stipulation was subject to Afghanistan's assurance that it would not build such a dam on its territory in the frontier sector, as it would diminish water flow from this river to Soviet territory. ${ }^{42}$

In $195^{8}$ Afghanistan and the former USSR signed a new, more detailed treaty. The treaty endorsed the frontier, which was determined by, inter alia, the 1946 Agreement. It elaborated rules on the maintenance of frontier marks and clearings. The Treaty also dealt with the utilization of frontier water and the main roads intersecting the frontier line as well as fishing, hunting, mining, agriculture, and forestry. In addition, since bilateral agreements commonly establish joint institutions to operationalize state parties' intention to cooperate on certain issues, the 1958 treaty provided for such a joint commission and set out its powers. The commission is statutorily tasked with the responsibility to cooperate in performing the duties arising from the treaty. Information exchange, which is an essential element in the effective implementation of the treaty, was also incorporated into the 1958 agreement. It obliged both parties to regularly exchange information on water levels and volumes in frontier rivers and precipitation to prevent flood dangers or damage. The question of sharing the water of the Amu Darya was left for a separate agreement. Article 16 of the treaty provided that 'questions concerning the use of waters that are connected with frontier waters shall be governed by special agreement between the Contracting Parties.' The explanation for leaving the Amu Darya watersharing issue to a separate agreement was that Afghanistan's use of Amu Darya at that time was limited and it was not capable of expanding or initiating any projects in the northern area. ${ }^{43}$

In the 1970s, Afghanistan made some efforts to negotiate a water-sharing treaty over the Amu Darya, but these produced no results. The reason for the failure of these negotiations inter alia, was the coup d'état in April 1978 that led to decades of unrest. ${ }^{44}$ Similarly, the Afghan government has striven to collaborate with its neighbouring countries in post-Taliban Afghanistan and concluded several Memoranda of Understanding (MoU) on data sharing and information exchange. In 2007, an MoU was signed between Afghanistan and Tajikistan with reference to and based on the 1958 Agreement, to cooperate and implement

42 ibid third letter annexed to the Agreement.

43 Qaseem NAIMI, 'Conflict Prevention and the Politics of Central Asian Water Cooperation from the Point of View of Afghanistan' (Seminar on Regional Water Resources and Conflict Prevention in Central Asia, Almaty April 2005) 6; UNEP et al, Environment and Security in the Amu Darya Basin (ENVSEC, UNEP 2O11) 44. 
joint water resource development projects. ${ }^{45}$ Similarly, in 2010 a Protocol was signed between Afghanistan and Tajikistan with reference to and based on the 1958 Agreement to exchange water from either side of the Amu Darya to provide the concerned population with drinking water. Likewise, in 2014, both governments signed another MoU making it imperative for Afghanistan and Tajikistan to exchange hydrological data and information on a regular, mutually beneficial, and free-of-charge basis. ${ }^{46}$

To summarize, the MoUs with Tajikistan regarding the information exchange and cooperation over Amu Darya were concluded with the intent of implementing the 1958 Agreement, which continues to remain important. However, even though these treaties and MoUs are in force, parties have taken few concrete actions for the implementation of these agreements. ${ }^{47}$

\subsection{Agreements among the cARs}

As discussed earlier, Afghanistan has never been part of any water-sharing agreements on the Amu Darya, and agreements concluded between Afghanistan and former UssR/Russia had not specified the share of Afghanistan in the Amu Darya. These treaties primarily deal with border issues. The water-sharing treaties have mainly been signed among the CARs to which Afghanistan is not a party.

The history of water sharing from the Amu Darya dates back to the $198 \mathrm{os}$ when the USSR conducted several meetings to determine the share of the four Soviet Republics in the Amu Darya Basin. ${ }^{48}$ The outcome of these meetings was the adoption of the abovementioned Protocol 566 by the Scientific and Technical Council of the UssR's Ministry of Water Resources in $1987 .^{49}$ Protocol 566 determined the quotas of Tajikistan, Uzbekistan, Turkmenistan, and the Kyrgyz Republic in the Amu Darya River Basin (see Table 1). The protocol authorized the extraction of $61.5 \mathrm{bcm}$ from the Amu Darya by the four CARs. The objective was to limit water extraction from the Amu Darya and secure additional flows to the Aral Sea, as the USSR was concerned about the sea drying up. ${ }^{50}$ Protocol 566 presumed that Afghanistan would divert 2.1 cubic kilometres of water from the Amu Darya Basin. Moreover, the River

Afghanistan-Tajikistan $2007 \mathrm{MoU}$ (n 8); see Walter KLEMM and Sayed S SHOBAIR, 'Impact of Irrigation in Northern Afghanistan on Water Use in the Amu Darya Basin' (2010) Investment Centre Division, FAO Rome 6.

46 Afghanistan-Tajikistan $2014 \mathrm{MoU}$ (n 8).

47 Walter KLEMM and Sayed SHOBAIR (n 45) 6.

48 WEHERICH, 'Hydro-hegemony in the Amu Darya Basin' (n 15) 76.

49 ibid.

$50 \quad$ Masood AHMAD and Mahwash WASIQ (n 1 1) 33.
} 
TABLE 1 Water allocation quotas as per Protocol 566

\begin{tabular}{lcc}
\hline Country & BCM per year & Percentage \\
\hline Kyrgyzstan & 0.40 & 0.6 \\
Tajikistan & 9.50 & 15.4 \\
Turkmenistan & 22.0 & 35.8 \\
Uzbekistan & 29.60 & 48.20 \\
Total & 61.50 & 100.00 \\
\hline
\end{tabular}

Basin Organization Basseynoe Vodnoe Ob'edinenie (BVo) was established and tasked with the responsibility of managing and enforcing quotas. Protocol 566 , in fact, favoured Uzbekistan and Turkmenistan; it neglected one of the significant contributors to the Amu Darya and upper riparian, namely Afghanistan, and used Tajikistan as a water regulator of the Amu Darya. ${ }^{51}$

The USSR disintegrated in 1991. The newly independent CARs then concluded a new agreement over the management of the Amu Darya and the Syr Darya, the Almaty Agreement. ${ }^{52}$ They also established new institutions and organizations to manage the Amu Darya and Syr Darya, such as ICWC, Interstate Commission for the Aral Sea (ICAS), and International Fund for saving the Aral Sea (IFAS).

Under the Almaty Agreement, the CARs agreed to maintain the existing water allocation pattern, ${ }^{53}$ which was determined by Protocol 566 for the Amu Darya Basin. The Almaty Agreement acknowledged the 'equal rights and responsibilities' of the parties to use and protect the water. The ICWC and its executives were statutorily tasked with observing the agreed order of water use, determining water management policy, and approving water use limits. ${ }^{54}$ The decisions made by the ICWC on water withdrawal limits, use, and protection of water resources are binding for all water consumers and water users. The phrase 'water consumer and water user' indicates that the agreement imposes an implied obligation on a third state, i.e., Afghanistan, which is not a party to the treaty. Nevertheless, the country uses a significant amount of water from the Amu Darya. The legal implications of such obligations are discussed in the next section. The Almaty Agreement also requires the parties to prevent

\footnotetext{
51 WEGERICH, 'The New Great Game' (n 24) 119.

$5^{2}$ Almaty Agreement ( $\mathrm{n} 7$ ).

53 ibid Preamble.

54 ibid articles $7-8$.
} 
actions that could cause damage, pollute water sources, violate the interests of other parties, or cause deviations from the agreed value of water discharge.

Furthermore, for the effective implementation of the Almaty Agreement, the parties must exchange information and cooperate in the management of water resources. ${ }^{55}$ The Almaty Agreement also provides for dispute settlement and recommends that differences be resolved by the heads of the water management agencies of the republics along with, if necessary, an independent representative's participation. However, the agreement does not provide a timeframe for resolution of disputes. Thus, if the ICWC fails to resolve an issue, what other remedies do state(s) have?

In 1992, the CAR s established the IFAS to generate funds for the management of the Aral Sea Basin. They also established the Interstate Commission for the Aral Sea (ICAR), which oversaw the Aral Sea. The IFAS was restructured in 1997 by a decision of the heads of the member states. The decision led to the merger of IFAS and ICAR. Following that, in 1999, the CARs entered into a new agreement, where all institutions and organizations were merged into the IFAS. ${ }^{56}$ The purpose of this amalgamation was to simplify the procedures and reduce duplications because the creation of a single institution to direct the terms of use and cooperation between member state(s) creates a window of opportunity to avoid institutional conflicts. However, the hierarchy and relations of each of these organizations and institutions was not specified in the agreement, which has led to various interpretations of the whole structure of cooperation under the IFAS. This situation created problems in establishing an unambiguous line in these bodies' interaction with each other. ${ }^{57}$ The main objective of IFAS was 'to finance and credit joint practical measures, programs, and projects for saving the Aral Sea, ecological rehabilitation of the Aral Sea surroundings and Aral Sea Basin as a whole, taking into account the interests of all states in the region. 58 The 1999 agreement about the status of the IFAS and its organizations gives legal personality to the IFAS organizations, which are competent to conclude contracts, act as claimants and respondents, and

55 ibid articles 5, 7, 8, 9 and 11 .

56 Article 1 of the agreement mentions that the IFAS includes a board, a revision committee, an executive committee, branches of the executive committee for the states of Central Asia, the ICWC, the secretary of the ICWC, the Scientific-Information Centre (sIC ICWC), the Amu Darya and Syr Darya Basin Water-Economic Organizations (BWos), the Commission on Sustainable Development (CSD), a secretary, and the ScientificInformation Centre at the Institute of Deserts of Turkmenistan (SIC CSD).

57 'Strengthening the Institutional and Legal Frameworks of the International Fund for Saving the Aral Sea: Review and Proposals' (2010) Discussion Paper $14<$ https://unece.org/ DAM/env/water/cadialogue/docs/Draft_Paper_united_FINAL_ENG.pdf >.

$5^{8}$ See $<$ http://ec-ifas.waterunites-ca.org/aral_basin/institutions/ifas/index.html $>$. 
obtain and dispose of property. Of the 12 articles, ten are dedicated to the organizations' privileges and immunities and the privileges and immunities of IFAS personnel. The legal status of the IFAS is not established by the agreement. ${ }^{59}$

Another agreement that deals with the Amu Darya is the statute of the ICWC adopted on 5 December 1992. The ICWC was established under Article 7 of the Almaty Agreement. Article 7 of Almaty Agreement provides:

The Parties decided to establish Interstate Commission for Water Coordination on a parity basis to deal with the issues related to regulation, rational use and protection of water resources from interstate sources, which would be comprised of the heads of water agencies to meet quarterly and as the occasion requires - on the Parties' initiative. ${ }^{60}$

The Commission was given a mission to ensure that water is allocated and used in a coordinated way. ${ }^{61}$ The ICWC, which was heavily grounded in preUSSR institutions and practices, was strengthened by the establishment of the Scientific Information Centre (SIC). The main objectives of the ICWC under the 1992 Statute are to determine a unified water policy, approve annual water consumption limits for each state, create a unified information system on water resource use and coordinate joint research on regional water problems. ${ }^{62}$ It has been statutorily tasked with the responsibility of approving water intake limits from water resources, and its decisions are binding upon all parties. ${ }^{63}$

In 2008, the Statute of ICWC was redrafted; however, to date, it has not been adopted. The reason is that the ICWC takes its decisions by consensus. In the case of a new statute, the ICWC could not reach unanimous decisions, as the parties had differences over the provision related to the rotation of the ICWC executive and over hosting regional organizations, which required stable funding from national budgets, and all CARs were not ready to secure it. ${ }^{64}$ The 2008 ICWC statute is more detailed. It empowers the ICWC to solve water management issues and implement common programs following the principles of

\footnotetext{
59 'Strengthening the Institutional and Legal Framework' (n 57) 11.

6o Almaty Agreement ( $\mathrm{n}_{7}$ ).

61 Dinara ZIGANSHINA, 'Central Asia: The Aral Sea Basin' in Stephen C MCCAFFREY, Christina LEB and Riley T DENOON (eds), Research Handbook on International Water Law (Edward Elgar 2019) 426.

62 ICWC Statute $1992\left(\mathrm{n}_{7}\right)$ article 2.

63 ibid article 5.1.

64 Author's email communication with Deputy Director, Scientific Information Center of Interstate Commission for Water Coordination in Central Asia.
} 
collectivism and mutual respect of parties' interests. ${ }^{65}$ Under the 2008 Statute the ICWC-tasks were increased and modified to some extent. The main objectives of ICWC, inter alia, are to elaborate and implement a regional policy of efficient shared water use and protection that meet social, economic, and environmental needs of the parties on equitable basis, ${ }^{66}$ to apply IWRM principles for the management of Aral Sea basin, ${ }^{67}$ to approve annual limits of water withdrawal and water allocation management, ${ }^{68}$ to ensure annual releases for environmental flow to the Aral Sea and establishing sanitary releases. ${ }^{69}$ The executive body of ICWC in a newly drafted Statute has been expanded and include the Secretariat, Amu Darya Basin Water-Economic Organizations (hereinafter Bwo), Syr Darya Bwo, Scientific Information Centre (sIC), the Coordination Metrological Centre (смC), and the Training Centre (тC) and are empowered to facilitate cooperation, information exchange and joint research and development. ${ }^{70}$ All these bodies have the status of international organizations. ${ }^{71}$ The Statute has a mechanism for the settlement of disputes, which states that if differences arise the decision of ICWC will be final regarding regulation, use and protection of shared waters. ${ }^{72}$ Furthermore, the Statute calls upon members to ensure the execution of the ICWC's decisions on their territories. ${ }^{73}$ However, it did not mention the timeframe for the execution of ICWC decisions and, in case the Member-State did not execute the decisions, what other remedies the ICWC has to make sure that its decisions are implemented.

The heads of the CARs have adopted several declarations and statements on water-related matters. These instruments are the Nukus Declaration (1995), Ashgabat Declaration (1999), Tashkent Statement (2001), Dushanbe Declaration (2002), and Joint Statement of the Heads of States - Founders of IFAS (2009). Notwithstanding the fact that these declarations are soft law, some provisions seek to regulate water-related matters by establishing guiding principles and modifying regional institutional bodies. The language of these declarations (shall, decide, duties) demonstrates their legal significance.

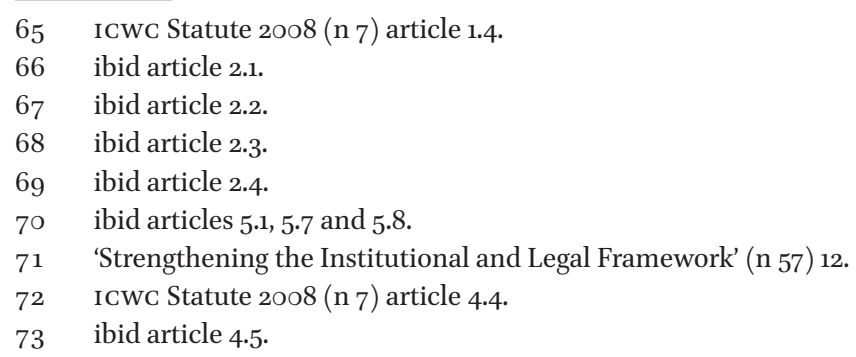


To conclude, Amu Darya is governed by a range of treaties, bilateral and regional; however, the Amu Darya basin still lacks a watercourse-specific agreement that encompasses the entire basin and involves all riparian countries, including Afghanistan. As noted, the Almaty Agreement fails to include Afghanistan or to encapsulate the Amu Darya's catchment area within the provisions of a joint management framework.

Legal Implications of Afghanistan's Exclusion from Transboundary Water-Sharing Agreements

As discussed earlier, Afghanistan was excluded from the 1987 meetings leading to the adoption of Protocol 566, which allocates the water of the Amu Darya among the four CARs. Protocol 566 estimated Afghanistan's water withdrawal from the Amu Darya at 2.1 billion cubic meters per annum. Afghanistan was excluded from the Almaty Agreement and other agreements that established institutions and organizations to manage the Aral Sea Basin, including the Amu Darya Basin. The legal implications of Afghanistan's exclusion from regional agreements regulating the Amu Darya will be discussed in this section.

\subsection{VCLT and Third States' Rights and Obligations}

The Vienna Convention on the Law of Treaties (VCLT) ${ }^{74}$ was adopted in 1969. Afghanistan is a signatory, but it never ratified the Treaty. On the other hand, the CARs (Tajikistan, Uzbekistan, Turkmenistan, Kyrgyzstan, and Kazakhstan) have acceded to the VCLT and thus are parties to it. The first issue that needs to be briefly addressed is that whether the VCLT applies to the treaties that were discussed above. The general rule of international law is that treaties apply between the parties, they are voluntary, and no state can be bound without its consent. Moreover, a treaty may codify or develop the customary international law, in such a case, non-parties to the treaty may be bound by customary rules which has the same content as the treaty. ${ }^{75}$ The VCLT has non-retroactive effect and applies only to treaties which are concluded after the entry into force of the VCLT, however, it does not bar the application of customary international law. Therefore, many provisions of VCLT which are recognized as rules

74 Vienna Convention on the Law of Treaties, Vienna 8 ILM 679 (1969) (hereinafter VCLT).

75 Martain DIXON, Textbook on International Law (OUP 2013) 28-29. 
of customary international law, applies to the treaties concluded between Afghanistan and former the USSR/Russia and between CARs. ${ }^{76}$

It is evident under the VCLT and customary international law that 'a treaty does not create either obligations or rights for a third State without its consent. ${ }^{77}$ Consequently, a treaty, whether bilateral, regional, or multilateral, cannot impose any obligation on a third state or in any way alter a third state's legal rights without its consent. However, the VCLT provides two conditions; if they are fulfilled, a treaty may impose an obligation. The first condition is that the parties to a treaty intend for a treaty provision to create a responsibility for a third state. The second condition is that the third state expressly and in writing accept that obligation. ${ }^{78}$ For treaties that provide for rights of third state(s), the prevailing view is that no rule of international law prohibits states from creating rights in favour of a third state. ${ }^{79}$ However, treaties cannot alter a third state's rights without its consent. The VCLT requires that a right arise for a third state from a provision of a treaty if the parties to the treaty intended so and the third-party consents. ${ }^{80}$

Furthermore, the VCLT states that a treaty may establish or formulate a rule of customary international law that will apply to a third state, albeit not as treaty law. ${ }^{81}$ There are many examples of the codification of customary

76 See Oliver DÖRR and Kirsten SCHMALENBACH (eds) Vienna Convention on the Law of Treaties: A Commentary (Springer 2012) 85; the book refers to around 57 articles of VCLT which are recognized as rules of customary international law and which were existed prior to vCLT. Article 34 to 36 which deals with third party rights and obligations are among these rules which are recognized as rules of customary international law.

$77 \operatorname{VCLT}(\mathrm{n} 74)$ art 31. The jurisprudence of international courts and tribunals shows that the content of Articles 34 to 36 reflects customary international law. For instance, the Permanent Court of International Justice (PCIJ) in the Free Zones of Upper Savoy and District of Gex case held that 'Article 436 of the Treaty of Versailles is not binding upon Switzerland, who is not a Party to that Treaty, except to the extent to which that country accepted it'. Case of the Free Zones of Upper Savoy and the District of Gex (Switzerland v France) PCIJ Rep Series A/B No 46, 141.

Similarly, in Certain German Interest in Polish Upper Silesia case the court noted that '[a] treaty only creates law as between the States which are parties to it; in case of doubt, no rights can be deduced from it in favour of third States'. Certain German Interests in Polish Upper Silesia (Germany v Poland) (Merits) PCIJ Ser A No. 7. 29. In Anglo-Iranian Oil $\mathrm{Co}$. case the ICJ held that '[a] third-party treaty, independent of and isolated from the basic treaty, cannot produce any legal effect as between the United Kingdom and Iran: it is res inter alios acta. Anglo-Iranian Oil Co Case ((United Kingdom v. Iran) (Jurisdiction) [1952] ICJ Rep 93, 109.

78 ibid art 35 .

79 Anthony AUST, Modern Treaty Law and Practice (CUP 2007) 256.

8o $\operatorname{vCLT}(\mathrm{n} 74)$ article 36.

81 ibid article 38 . 
international law by the International Law Commission (ILC), such as the substantive and procedural rules of the 1997 UN Convention and the VCLT itself. The substantive principles of these two conventions also apply to non-parties, not as treaty obligations, but as rules of customary law.

Hence, it is evident that the Almaty Agreement and other agreements cannot create either rights or obligations for Afghanistan without its consent. Protocol 566's quotas, which were confirmed by the Almaty Agreement, do not apply to Afghanistan, and Afghanistan will not be held liable if it breaches any provision of these agreements, because it is not a party to them. However, those provisions of the Almaty Agreement and other agreements that incorporated principles of customary international law apply to Afghanistan as a customary international law rule. Afghanistan and the CARs are bound to adhere to these principles of customary international law. The 1997 UN Convention codified some customary international law principles, such as equitable and reasonable utilization, the obligation not to cause harm to other riparian states, and the duty to cooperate. There is no legal document that indicates that Afghanistan and the CAR s have been persistent objectors to the 1997 UN Convention with the existing treaties that govern the water allocation in the Amu Darya basin.

The 1997 UN Convention encourages states to enter into an agreement over a shared watercourse and become parties to the convention while 'considering harmonizing' existing agreements with the 'basic principles' of the convention. ${ }^{82}$ However, the convention does not affect or modify the rights and obligations arising from a specific agreement over a transboundary watercourse. ${ }^{83}$ What can be understood from the language of Articles 3(1) and $3(2)$ is that states are allowed to preserve the existing agreements but can '[consider] harmonizing' such agreements with the fundamental principles of the 1997 convention. The language of Article 3(2) explicitly shows that harmonization with the UN Convention is not mandatory, and whether to amend the agreement for purposes of harmonization is up to the state parties. Moreover, states are not bound to agree to share a watercourse before using its water ${ }^{84}$ Therefore, to utilize international watercourses, riparian states are not bound to make an agreement. The ILC Commentary on Article 3 of the 1997 UN Convention provides that the requirement to make an agreement as a precondition to using the water of an international watercourse would mean giving

82 UN Convention 1997 (n 9) article 3(2); Stephen C MCCAFFREY, The Law of International Watercourses (Ou 2007) 360-361.

83 UN Convention 1997 (n 9) article 3(1).

84 ILC, 'Draft Articles on the Law of the Non-Navigational Uses of International Watercourses' (1994) II Part 2 Yearbook of International Law Commission 94. 
the riparian state the power to veto the use of water by the co-riparian states or providing power to states to refuse the conclusion of an agreement over the shared watercourse. Such a result is supported neither by state practice nor judicial decisions or the terms and intent of Article $3 .{ }^{85}$

Article 3(4) provides that states may enter into an agreement over an entire watercourse or part of it; they may not adversely affect to a significant extent the uses of other watercourse states without their express consent. Similarly, under Article 3(6), non-parties are protected by explicitly stating that their rights and obligations would not be affected by a specific watercourse agreement over a shared watercourse. In other words, Article $3(6)$ protects the rights of states that are not parties to a partial agreement but are parties to the convention. Accordingly, Article 3(6) upholds Article 34 of the Vienna Convention, which affirms that treaties create neither rights nor obligations for a third state without its consent. ${ }^{86}$

The 1997 UN Convention gives states the right to participate in negotiations and consultations and become a party to any agreement that applies to the whole or part of the watercourse. ${ }^{87}$ It also provides that

a watercourse State whose use of an international watercourse may be affected to a significant extent by the implementation of a proposed watercourse agreement that applies only to a part of the watercourse or to a particular project, programme or use is entitled to participate in consultations on such an agreement and, where appropriate, in the negotiation thereof in good faith with a view to becoming a party thereto, to the extent that its use is thereby affected. ${ }^{88}$

There have been some concerns about Article 4 in UN deliberations. For various reasons, a state may not want to include third countries sharing the same watercourse in negotiations or may prefer that other states not become parties to the agreement. ${ }^{89}$ The same concern was expressed about the partial agreements explained in Article 4(2) of the Convention. Furthermore, the inclusion of the phrase 'where appropriate' in Article 4(2) gives considerable leverage to

\footnotetext{
85 ibid.

$86 \operatorname{VCLT}(\mathrm{n} 74)$ article 34 .

87 UN Convention 1997 (n 9) article 4 (1).

88 ibid article $4(2)$.

89 MCCAFFREY, The Law of International Watercourses (n 82) 362.
} 
the original parties to an agreement to allow or not allow a state to become a party to the agreement over a shared watercourse. ${ }^{90}$

During the negotiations over the 1997 UN Convention, those countries that were 'well served by the existing agreements' argued for Article 4. They succeeded in incorporating this article into the convention, as their interests might have been better protected under existing agreements. As the UN Convention does not affect existing agreements or the rights and obligations arising out of a specific agreement, it was concluded that the inequitable agreements concluded under colonial basin plans, i.e., the Nile ${ }^{91}$ and Amu Darya ${ }^{92}$ Basin plans, would, therefore, not be affected. The new rules or convention would cover only basins that did not have an agreement. ${ }^{93}$

Therefore, as the 1997 UN Convention does not change the status quo and does not affect the existing agreements, the Almaty Agreement, which endorsed the allocation of water of Amu Darya that was determined by the USSR, will remain effective, even if the water allocation under the treaty is unreasonable and unequitable.

\subsection{Early and Late Developers and the Foreclosure of Afghanistan's Future Use}

The doctrine of equitable and reasonable utilization is broadly considered as 'general rule of law for the determination of the rights and obligations of States' in the field of international watercourse law. ${ }^{94}$ The principle is codified in Article 5 of the 1997 UN Convention which provides that watercourse states 'shall in their respective territories utilize an international water in an equitable and reasonable manner' and 'shall participate in the use, development and protection of an international watercourse in an equitable and reasonable manner'. Article 6 of 1997 UN Convention provides a non-exhaustive list that must be considered in determining the equitable and reasonable share of

9o Lucius CAFLISCH, 'Regulation of the Uses of International Watercourses' in Salman, MA SALMAN and Laurence B de CHAZOURNES (eds), International Watercourses Enhancing Cooperation and Managing Conflict (World Bank 1998) 12.

91 Exchange of notes between Great Britain and Northern Ireland and Egypt regarding the use of the waters of the River Nile for irrigation purposes (1929) (hereinafter 1929 Nile Agreement).

92 Allocation of Amu Darya water under Protocol 566 by UssR that was later confirmed by the Almaty Agreement.

93 Kai WEGERICH and Oliver OLSSON, 'Late Developers and the Inequity of "Equitable Utilization" and the Harm of "Do No Harm"' (2010) 35(6) Water International 710.

$94 \quad$ ILC (n 84) 98. 
each riparian state. ${ }^{95}$ These factors essentially favour downstream states that have already developed transboundary water resources against upstream late developers. WEGERICH and OLSSON argue that the criteria set by the 1997 UN Convention (eight out of eleven factors) and the Helsinki Rules (six out of seven) determine equitable and reasonable utilization of water resources refer to prior utilization of water resources. ${ }^{96}$ Therefore it protects the early developer uses and interests against the late developers. They argue that the factors determining equitable and reasonable utilization essentially closes the basin for late developers. ${ }^{97}$ In addition, under Articles 6(e) and (f) of the 1997 UN Convention, prior uses are preserved against new uses; nevertheless, Afghanistan, as a late developer, is not barred from claiming new uses, although it would be challenging to relocate prior uses. ${ }^{98}$ If Afghanistan is developing new uses, it has to show that it uses water efficiently, and proving that will be quite difficult.

Article 7 of the 1997 UN Convention provides for 'no harm rule' and require riparian states to prevent significant harm to other riparian states. Paragraph 2 of the same Article deals with a situation where 'significant harm' is nevertheless caused and require the state that caused such harm to take appropriate measures having due regard to Article 5 and 6 (equitable and reasonable utilization). The prevailing view is that the obligation not to cause harm is subordinated to the principle of equitable and reasonable utilization ${ }^{99}$ and this view is endorsed by the International Court of Justice in the Gabčkovo-Nagymaros

95 These factors include:

(a) Geographic, hydrographic, hydrological, climatic, ecological and other factors of a natural character;

(b) The social and economic needs of the watercourse States concerned;

(c) The population dependent on the watercourse in each watercourse State;

(d) The effects of the use or uses of the watercourses in one watercourse State on other watercourse States;

(e) Existing and potential uses of the watercourse;

(f) Conservation, protection, development and economy of use of the water resources of the watercourse and the costs of measures taken to that effect;

(g) The availability of alternatives, of comparable value, to a particular planned or existing use.

$96 \quad$ Kai WEGERICH and Oliver OLSSON (n 93) 710.

97 ibid $710-711$.

98 James C MCMURRAY and AD TARLOCK, 'The Law of Later-developing riparian States: The Case of Afghanistan' (2005) 12 New York University Environmental Law Journal $75^{2}$.

99 Salman MA SALMAN, 'The Helsinki Rules, the UN Watercourses Convention and the Berlin Rules: Perspective on International Water Law' (2007) 23(4) International Journal of Water Resources Development 633 . 
case $^{100}$ also, in which it emphasized on equitable and reasonable utilization and did not refer to the obligation not to cause harm. ${ }^{101}$ Similarly, paragraph 2 of Article 7 gives precedence to the principle of equitable and reasonable utilization over the obligation not to cause harm, ${ }^{102}$ and the 'very existence of a second paragraph implicitly acknowledging that harm may be caused without engaging the harming state's responsibility supports this conclusion. ${ }^{103}$ However, even if the no harm principle is subordinated to the principle of equitable and reasonable utilization, the factors that determine the equitable utilization are 'biased' towards the early developers and the late developers can only claim the water resources which have not yet been utilized. ${ }^{104}$ Thus, the conclusion may be that, the principle of equitable and reasonable utilization itself is 'inequitable', as it favours the early developers and consequently forecloses the future uses of late developers. Afghanistan as late developer in the Amu Darya basin could be harmed by the uses of CARs by way of foreclosing its future water rights. For Afghanistan, accession to the 1997 UN Convention or other multilateral treaties on international watercourses will not serve Afghanistan's interests as its water allocation rules favour early developers against the late developers.

Moreover, it is often assumed that only an upstream riparian state can harm their downstream counterparts. Thus, an upstream state must not pollute the river, divert the water for agricultural or industrial purposes, and build a dam or a canal if it causes significant harm to a downstream state. An upstream riparian state can indeed harm a downstream riparian state in various ways, such as pollution, building a dam or canal that diverts the water of shared river and which adversely affects the flow of the river or by leaving insufficient water for the ecology of the river. Similarly, the no-harm rule on its face seems to impose most of the obligations on the upstream state and gives most rights to the downstream riparian state. ${ }^{105}$ However, the idea that only upstream state

100 Case Concerning the Gabčikovo-Nagymaros Project (Hungary vs Slovakia) [1997] ICJ Rep 4. 101 SALMAN, 'The Helsinki Rules' (n 99) 634.

102 Stephen C MCCAFFREY, 'The UN Convention on the Law of the Non-Navigational Uses of International Watercourses: Prospects and Pitfalls' in Salman MA SALMAN and Laurence B de CHAZOURNES (eds), International Watercourses - Enhancing Cooperation and Managing Conflict (World Bank 1998) 22.

103 ibid.

104 Kai WEGERICH and Oliver OLSSON (n 93) 712.

105 Stephen C MCCAFFREY, 'Some Developments in the Law of International Watercourses' in Marcelo G KOHEN (ed), Promoting Justice, Human Rights, and Conflict Resolution through International Law (Martinus NijHoff Publishers 2007) 785. 
can harm the downstream counterparts is a misconception. ${ }^{106}$ Salman ${ }^{107}$ and McCaffrey ${ }^{108}$ argues that as downstream state can harm the upstream state, the upstream state can be harmed if their present or future use is limited in favour of the downstream state. The downstream riparian state can foreclose the future use by the upstream state due to their prior or past uses and latter claiming of rights to such water by downstream riparian. What happens in most of the cases is that the downstream state develop its infrastructure and water resources earlier than their upstream counterpart for various reasons. For example, in the case of CARs, especially in Uzbekistan and Turkmenistan, their flatter topography, which was readily available for agriculture, and climate which was more conducive for agriculture, helped them expand their cotton production to the extent that they become one of the largest cotton producers. On the other hand, an upstream state in many cases and particularly in Amu Darya (Tajikistan and Afghanistan), are best suited for hydroelectric power production and building dams because of mountainous topography; but it did not come into the scene until recently, long after the downstream state have well developed its uses. If the no harm rule is applied strictly and out of the context of an overall equitable and reasonable utilization it could lead us to a conclusion, where every new activity regarding the use of water by the later developing upstream state (such as Afghanistan) will be considered as violation of no harm rule as it interfered with established uses of a downstream state and thus causing significant harm. Consequently, the downstream state will be foreclosing or at least limiting future uses of the upstream state and the upstream state will have no legal recourse. ${ }^{109}$

In the Blue Nile Basin case, which shares many similarities with the Amu Darya Basin case, Egypt and Sudan have argued in favour of their historical and natural rights to utilize the Blue Nile. Egypt, along with Sudan, the downstream riparians, consistently objected to the construction of the Grand Ethiopian Renaissance Dam (GERD) across the Blue Nile by Ethiopia, an upstream riparian. Egypt's arguments are based on the colonial-era 1929 and 1959 agreements that prevent the upstream states from constructing any major infrastructure over the Blue Nile. ${ }^{110}$ Egypt's main argument is that the 1929 Agreement is still

\footnotetext{
106 Salman MA SALMAN, 'Downstream Riparians Can also Harm Upstream Riparians: The Concept of Foreclosure of Future Uses' (2010) 35(4) Water International 351.

107 ibid.

108 MCCAFFREY (n 105) 788.

109 SALMAN (n 106) 786.

1101929 Nile Agreement (n 91) article 4(iii): 'Except with the prior consent of the Egyptian Government, no irrigation works shall be undertaken, nor electric generators installed along the Nile and its branches....'
} 
binding on the British East African Colonies, based on the theory of universal succession. ${ }^{111}$ Thus, Egypt argues that under the 1929 Agreement, its consent is required in case the upstream states initiate any water-related project. Similarly, the 1959 agreements between Egypt and Sudan, which excluded Ethiopia and other riparians, have allocated the Nile's water between these two countries without affording a share in the water to the upstream countries, particularly Ethiopia, ${ }^{112}$ which contributes 80 percent of total water. Most importantly, under these agreements, Egypt does not need the consent of upstream states to undertake a project over the river; however, the agreement has granted Egypt the power to veto projects in the upstream countries, ${ }^{113}$ which essentially forecloses the future use of the upstream countries such as the constructing of the GERD. In the case of Amu Darya, as the use of Afghanistan is still modest, therefore, no such problem exists in the Amu Darya basin in comparison to the situation in the Nile. However, if Afghanistan develops its water resources, expands its use, or initiates any major infrastructure over the Amu Darya, it could become a leading cause of tension between Afghanistan and cAR s.

On the other hand, contrary to the above discussion that the principle of equitable and reasonable utilization itself is 'inequitable' (as it protects the early developers against the late developers), this article argues that the principle of equitable and reasonable utilization gives all riparians an equal right to equitably utilize a shared watercourse, and thus not all new uses by late developers constitute a violation of the no-harm rule. The broader understanding of the principle of equitable and reasonable utilization is that it gives all riparian states a right to an equitable share in shared water resources, or in other words, states have an equal right to an equitable share to use and benefit from a shared river. In this context, the term 'equitable' is not synonymous with 'equal': every riparian state has the right to use water equitably, but they are not entitled to an equal share in the water. ${ }^{114}$ Therefore, the upstream state may, initiate new uses (i.e., build a dam, canal or divert water for agricultural propose) of shared water resources which is consistent with the principle of equitable and reasonable utilization even if the result of such uses cause harm to downstream state. ${ }^{115}$ However, if the new uses are such that they 'significantly' harm the downstream state, then in that case the upstream new uses will be

\footnotetext{
111 Mahemud TEKUYA, 'The Egyptian Hydro-Hegemony in the Nile Basin: The Quest for Changing the Status Quo' (2020) 26(2) The Journal of Water Law 12.

112 Agreement Between the Republic of Sudan and the United Arab Republic Egypt on the Full Utilization of the Waters of the Nile 453 UNTs 6519 (1959).

1131929 Nile Agreement (n 91) article 4(iii).

114 ILC (n 84) 98.

115 MCCAFFREY (n 105) 787.
} 
'inequitable' and thus a violation of the principle of equitable and reasonable utilization. Similarly, the World Bank practice is such that it requires the riparian state to notify each other regarding the planned measure. The World Bank policy clearly indicates that it did not accept the upstream and downstream approach, and its policy extends equally to all watercourse states. ${ }^{116}$ Thus, the riparian states of a shared watercourse need to formally notify each other regarding the proposed project. The downstream states (CARs in this case) are also required to formally notify about their planned projects to the upstream (Afghanistan in this case), as their projects may foreclose the future uses of upstream Afghanistan and hence may significantly cause harm to it.

To conclude, the broader definition of the principle of equitable and reasonable utilization is that downstream CAR s cannot prevent upstream Afghanistan from developing their water resources. However, upstream Afghanistan cannot claim the river's entire flow, which originates inside Afghanistan. Hence, a middle ground that harms neither late nor early developers must be sought.

\section{7}

\section{Conclusion}

Although effective and sustainable transboundary water management is dependent on all riparian states' participation in the management of a river basin, the regional legal and institutional framework governing the Amu Darya has excluded Afghanistan, an important stakeholder, and a significant contributor to the Amu Darya, from shared water resource management. The legal implications of Afghanistan's exclusion from regional agreements and institutions are that these agreements create neither rights nor obligations, and that Afghanistan is not bound to implement the water allocation quotas under these agreements. Furthermore, the 1997 UN Convention encourages states to participate in negotiations and consultations over the shared river; it also entitles all riparian states to become parties of an agreement governing a shared watercourse, although it is not mandatory. Hence, state parties to existing agreements, such as the parties to the Almaty Agreement, have been given considerable leverage on whether to allow a state to become a party to a shared watercourse agreement. Consequently, if an agreement governing a transboundary watercourse such as the Amu Darya is inequitable and unreasonable, it is not to be affected by the 1997 UN Convention's provisions.

116 Raj KRISHNA, 'The Evolution and Context of the Bank Policy for Projects on International Waterways' in Salman MA SALMAN (ed), International Watercourses - Enhancing Cooperation and Managing Conflict (World Bank 1998) 40. 
Therefore, accession to the 1997 UN Convention will not benefit Afghanistan particularly because the Convention does not affect the existing agreements. Finally, it is not only the upstream states that harm the downstream states; harm can be caused by upstream states also by foreclosing the future use of downstream states. Extensive use of a shared watercourse such as the Amu Darya by downstream CARs clearly violates the 'no harm' rule under international law. Thus, early developers have an equal obligation not to cause significant harm to the future use by late developers.

\section{Acknowledgement}

This article is financially supported by Tarzi Research Foundation, Kabul, Afghanistan. The author would like to thank Dr. Stellina JOLLY, Assistant Professor, South Asian University, Dr. Ravindra PRATAP, Associate Professor, South Asian University; and Dawood MOHAMMADI, Deputy Director, Tarzi Research Foundation, for their intellectual guidance and moral support. 